\title{
Ice-marginal characteristics of Fridtjovbreen (Svalbard) during its recent surge
}

\author{
NEIL F. GLASSER. DAVID HUDDART and MATTHEW R. BENNETT
}

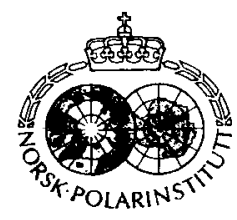

Glasser, N.F., Huddart, D. \& Bennett, M.R. 1998: Ice-marginal characteristics of Fridtjovbreen (Svalbard) during its recent surge: Polar Research $17(1), 93-100$

Fridtjovbreen is an actively surging tidewater glacier in western Spitsbergen, Svalbard. This paper presents observations made at the western flank of the glacier in July 1997, when the glacier front was still advancing rapidly and was characterised by steep lateral ice cliffs. The geomorphological consequences of the surge include the formation of push moraines from toppled ice blocks along this ice cliff and the development of debris-rich thrusts. There is also evidence of glaciotectonic deformation within deformed debris-rich thrusts. Thrusts are restricted to the lateral margins and are not seen in the terminal calving cliff. On its western flank, Fridtjovbreen is over-riding Sagabreen, a small-tributary glacier. Large facies variations in this area are a result of recycling by Fridtjovbreen of material originally transported as medial moraines on Sagabreen. There are few observations of landform development at actively surging glaciers in Svalbard. The Fridtjovbreen descriptions provide documentation for post-surge landform development. More observations are required at the margins of actively surging glaciers to determine how representative Fridtjovbreen is of a surge event.

N.F. Glasser, School of Biological and Earth Sciences, Liverpool John Moores University, Byrom Street, Liverpool L3 3AF, UK; D. Huddart, School of Education and Community Studies, Liverpool John Moores University, I. M. Marsh Campus, Liverpool L17 6BD, UK; M.R. Bennett, School of Earth and Environmental Sciences, University of Greenwich, Medway Campus, Chatham Maritime, Kent ME4 4AW, $U K$.

\section{Introduction}

The aim of this paper is to document the icemarginal characteristics of the glacier Fridtjovbreen (latitude $77^{\circ} 50^{\prime} \mathrm{N}$, longitude $14^{\circ} 26^{\prime} \mathrm{E}$ ) during a stage in its current surge in July 1997. Glacier surges are periodic or cyclic advances characterised by velocities one or even two orders of magnitude greater than during normal flow (Meier $\&$ Post 1969). The exact cause of glacier surges remains unclear (Raymond 1987), but current explanations for the increased velocities encountered during surge events involve changes in the basal drainage system (Kamb 1987) and enhanced motion due to the presence of a deformable bed (Clarke et al. 1984). Paradoxically, relatively few glaciers have actually been observed during a surge. Exceptions to this are the Medvezhiy Glacier in the Pamirs (Dolgushin \& Osipava 1973), Variegated Glacier in Alaska (Kamb et al. 1985) and Usherbreen in Svalbard (Hagen 1987). This lack of observations during active surge events is particularly true of the landforms and sediments produced by surges. The landform and sedimentary facies of surge-type glaciers have now been well described from a range of different locations (Sharp 1985, 1988; Boulton et al. 1996;
Bennett et al. in press); however, few observations have been made along ice margins during active surges.

In this paper we present observations made on the western flank of Fridtjovbreen in July 1997 and report the geomorphological impacts of the current surge. Hopefully these observations will provide an historical record of the glacier that can be used to document future changes and which will serve as a comparison with the landform record after cessation of the surge.

\section{Fridtjovbreen}

Fridtjovbreen (Glacier 13708 of Hagen et al. 1993 ) is a $13 \mathrm{~km}$-long (during quiescence) tidewater glacier in western Spitsbergen, Svalbard (Fig. 1). The glacier flows in a southeasterly direction down Fridtjovhamna which joins Van Mijenfjorden just to the east of Akseløya. The calving ice margin of Fridtjovbreen is currently located approximately $1 \mathrm{~km}$ to the northwest of the mouth of Fridtjovhamna (Fig. 1). Within the terminal zone of Fridtjovbreen there are two 


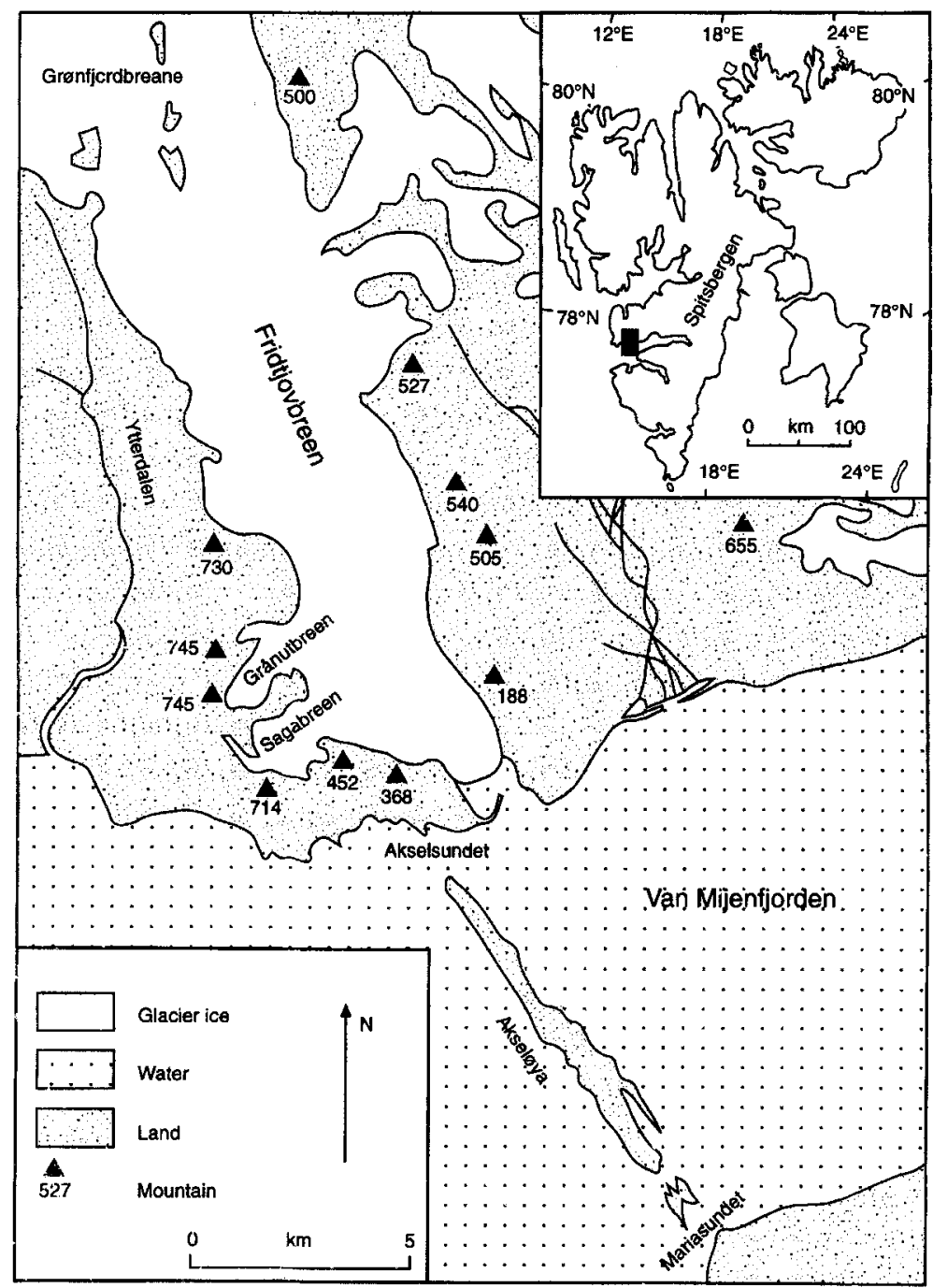

Fig. 1. The location of Fridtjovbreen and its two tributaries, Sagabreen and Grånutbreen, in Van Mijenfjorden, Svalbard.

tributaries, Sagabreen and Grånutbreen, which join the main glacier from the west (Figs. 1 and 2).

Radio echo-sounding of Fridtjovbreen has shown that, in common with many other Svalbard glaciers, it is polythermal in nature (Glazovsky \& Moskalevsky 1989). Polythermal glaciers have extensive areas of temperate ice beneath their accumulation areas but margins and snouts frozen to the bed (Björnsson et al. 1996; Hagen et al. 1991; Hagen \& Saetrang 1991; Ødegård et al. 1992). Fridtjovbreen is inferred to be a surge-type glacier, with the last recorded surge dated to approximately 1861 (Hagen et al. 1993). In 1860, the glacier is reported to have advanced into Fridtjovhamna and almost blocked Akselsundet (Fig. 1; Hjelle et al. 1986), although in the maps produced by Nordenskiold (1866) the glacier is depicted well inland of the modern coast. By 1909, Isachsen (1915) reported that the glacier was as level as a road with no crevasses, implying that it was in its quiescent phase at this time. Surge-type glaciers in Svalbard typically have relatively long quiescent phases between surge events (Dowdeswell et al. 1991). The length of these quiescent phases makes it difficult to separate historically-documented advances from 

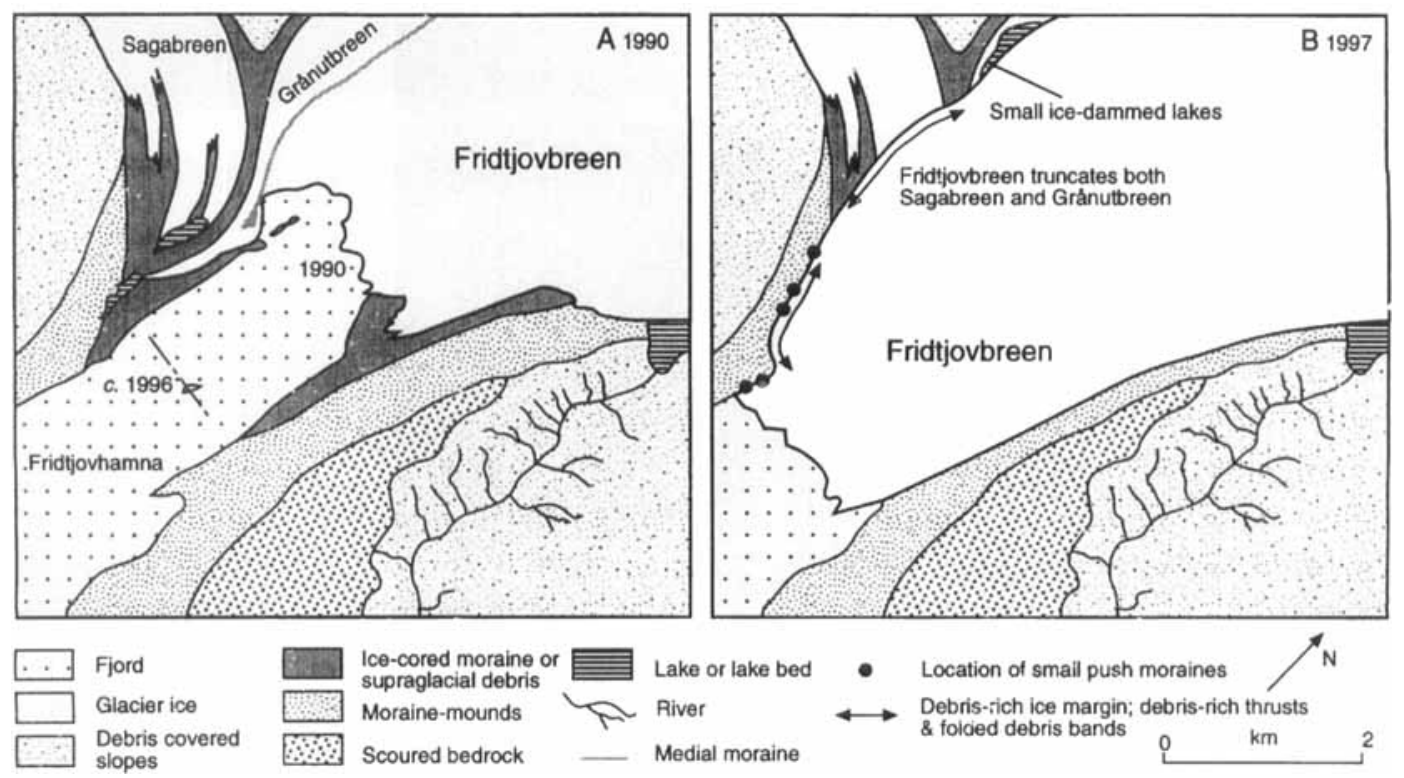

Fig. 2. Geomorphological maps of the terminal area of Fridtjovbreen showing the advance of the glacier between 1950 and 1997.

true surges, but the evidence presented above suggests that the 1861 advance of Fridtjovbreen constitutes a true surge event.

In recent years, most Svalbard glaciers have been in marked retreat (Etzelmüller \& Sollid 1996). Although there is little data specific to Fridtjovbreen, the glacier appears to follow this trend, and during the Twentieth Century there is evidence for rapid retreat (Glazovsky \& Moskalevsky 1989). Between 1936 and 1988 the glacier terminus retreated by 1.3 to $2 \mathrm{~km}$, whilst surface lowering in the terminal $7.5 \mathrm{~km}$ amounted to between 50 and $70 \mathrm{~m}$. During this period the glacier is estimated to have lost around $0.6 \mathrm{~km}^{3}$ of its volume (Glazovsky \& Moskalevsky 1989). The 1990 aerial photographs show the Fridtjovbreen ice front located to the northwest of Sagabreen in the centre of the Fjord, although both glaciers are still contiguous due to a complex of ice-cored medial moraines (Fig. 2). In 1995 the glacier began to advance rapidly and has advanced over $2.5 \mathrm{~km}$ down Fridtjovhamna in the last two years (Fig. 2). In 1997 the lower part of the glacier was extremely crevassed and its surface breken into large seracs. The calving front is steep, as are both lateral margins. In the upper regions of the glacier there is evidence, in the form of large extensional crevasses, for drawdown of the glacier in its accumulation zone (A.
Hodson, pers. comm. 1997). This rapid advance, together with evidence of draw-down in the accumulation area and previous cyclic advanceretreat behaviour, supports the assertion that Fridtjovbreen is a surge-type glacier currently in its active phase.

\section{The ice-marginal characteristics of Fridtjovbreen in 1997}

In July 1997 Fridtjovbreen was still advancing and had not reached the maximum extent of its surge. This observation is based on comparison with hand-held oblique photographs of the glacier taken in August 1996 (A. Hodson, pers. comm. 1997), the vertical calving cliff at the tidewater front, and the near-vertical lateral cliffs. The observations reported in this paper come primarily from the western margin, where the glacier was observed advancing over lateral moraines presumably formed during the 1860 surge. Along this margin the lateral cliffs are generally steep (nearvertical in places), up to 60 metres in height, and they expose evidence of complex glaciotectonic deformation of debris-rich ice within the glacier. A major lateral meltwater stream flows southward along this margin. The lateral clifi is highly 


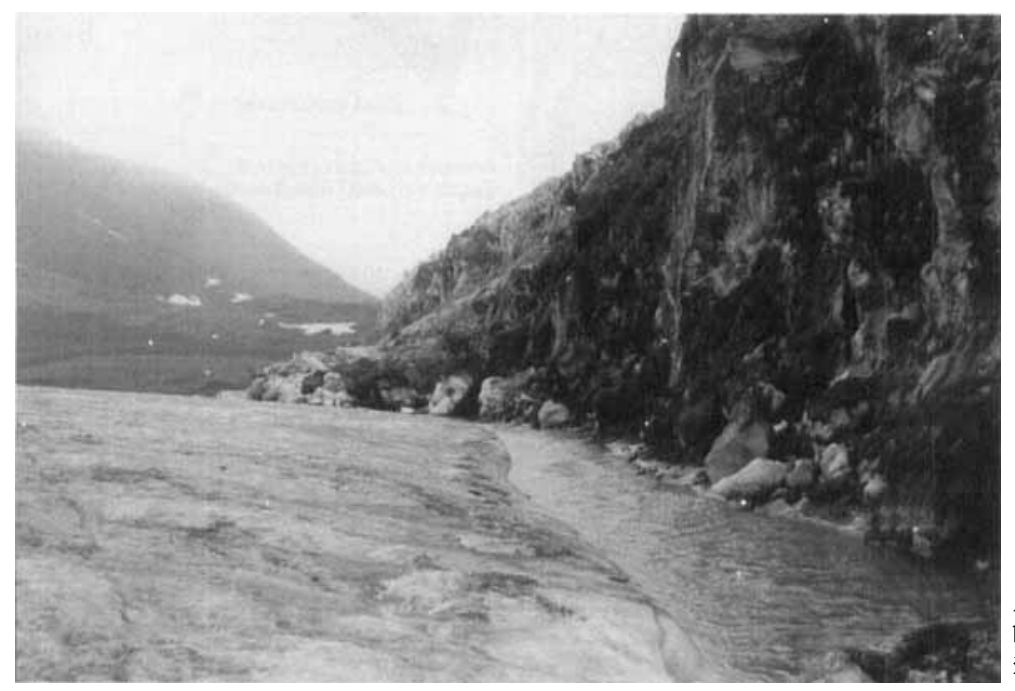

Fig. 3. Photograph of fallen ice blocks along the lateral ice-cliff in July 1997. crevassed, fractured and unstable. Large fallen blocks of ice are common, creating an irregular, indented ice margin (Fig. 3). In July 1997 the advance of Fridtjovbreen had impounded two small ice-dammed lakes immediately north of the confluence with Sagabreen (Fig. 2). These two lakes, approximately $100 \mathrm{~m}$ long, $25 \mathrm{~m}$ wide and of unknown depth, are impounded between the ice margin and the valley wall to the west.

There is no evidence for large-scale proglacial deformation in front of the advancing ice margin. The glacier is overriding older lateral moraines along the western flank and contains evidence of flow compression in the form of debris-rich thrusts and folds. Small superficial push moraines formed either beneath the advancing ice cliff, or in front of fallen ice-blocks (Fig. 4) dominate the contemporary landform assemblage.

The push moraines beneath the ice-cliff consist of wedges of diamicton. These extend for 40 to $50 \mathrm{~m}$ along the ice margin and taper rapidly beneath the cliff, from a height of 1 to 2 metres at the margin (Fig. 4). They appear to be formed by the accumulation of debris between the sole of the advancing glacier and the surface of the underlying, older, lateral moraines. The diamicton appears to be derived from the melt-out of debris-rich ice and is distinct in terms of clast shape, lithology and grain size from that of the underlying lateral moraines. This is further evidence for the polythermal nature of the glacier. Till wedges are a feature of the margins of polythermal glaciers, where basal debris is elevated along englacial thrusts due to flow compression at the thermal boundary.

The push moraines produced by ice-blocks occur in front of toppled ice blocks that have been subsequently pushed by the advancing ice cliff. They are more irregular in planform than the push moraines formed directly in front of the ice-cliff and are also much higher. Typical dimensions are within the range of 1 to $5 \mathrm{~m}$ high and up to $25 \mathrm{~m}$ long. These moraines are composed of diamicton ploughed from the upper surface of the older lateral moraines over which the glacier is advancing. The diamicton from which they are composed is less compacted than that of the older lateral moraines and gravity sorting frequently results in a rampart of larger boulders around the distal perimeter of the push moraine.

\section{Ice-cliff structures}

The surface of Fridtjovbreen is too heavily crevassed for detailed glacial structures to be visible in the field. However, along the western margin of the glacier a range of structures are exposed in the lateral ice-cliff. Detailed analysis is precluded by the fractured and broken nature of the glacier surface and by problems of access and safety. Nevertheless, the following observations were made.

Large thicknesses ( $>5 \mathrm{~m}$ ) of debris-rich ice occur at three locations along the western ice 


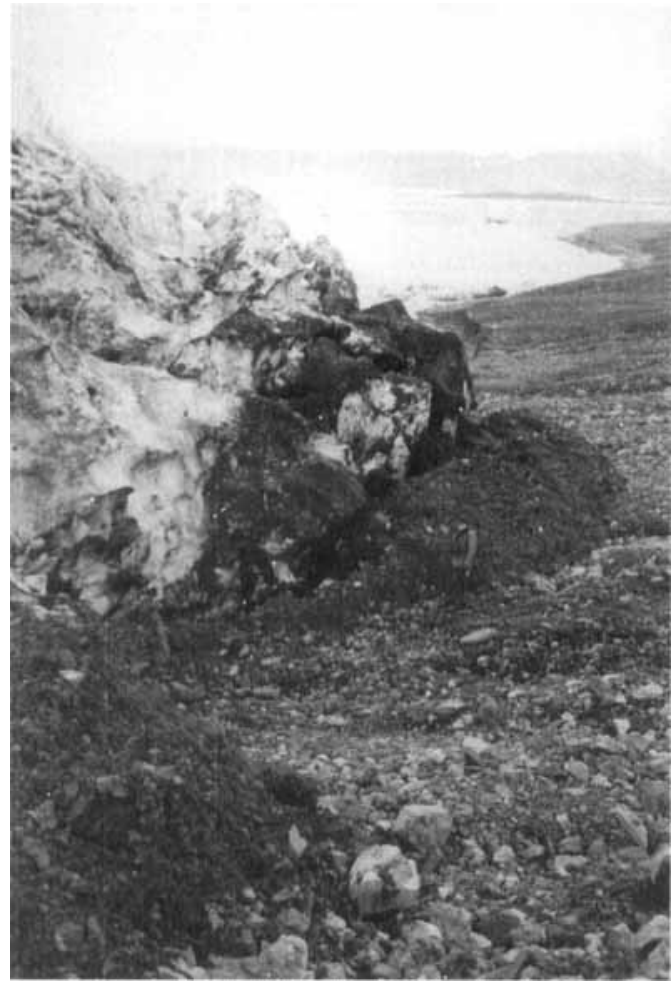

Fig. 4. Photograph of a well-developed push moraine on the western margin of Fridtjovbreen.

margin. These consist of segment- or wedgeshaped units of debris-rich ice located along the ice margin and separated from cleaner ice within the main body of the glacier by a sharp planer surface, interpreted as a thrust surface. Within these wedge-shaped units a complex mélange of debris rafts and ice blocks occurs. Debris bands vary from a few millimetres to over $6.5 \mathrm{~m}$ in one case. The tectonic geometry of the individual structures is not clear due to the number of displaced ice blocks present, although two broad scales of structure can be identified. Firstly, there are large debris rafts consisting of slabs of diamicton between 0.5 and $6.5 \mathrm{~m}$ thick. Many of these slabs have a planar geometry showing displacement of the stratification either side of the surface. Consequently these are interpreted as thrusts, common to both surge-type and non surge-type glaciers elsewhere (Lawson et al. 1994; Hambrey \& Huddart 1995; Bennett et al. 1996a; Hambrey et al. 1996). Bifurcations within several debris-rich thrusts were observed. Some of the thrusts appear to have been subsequently

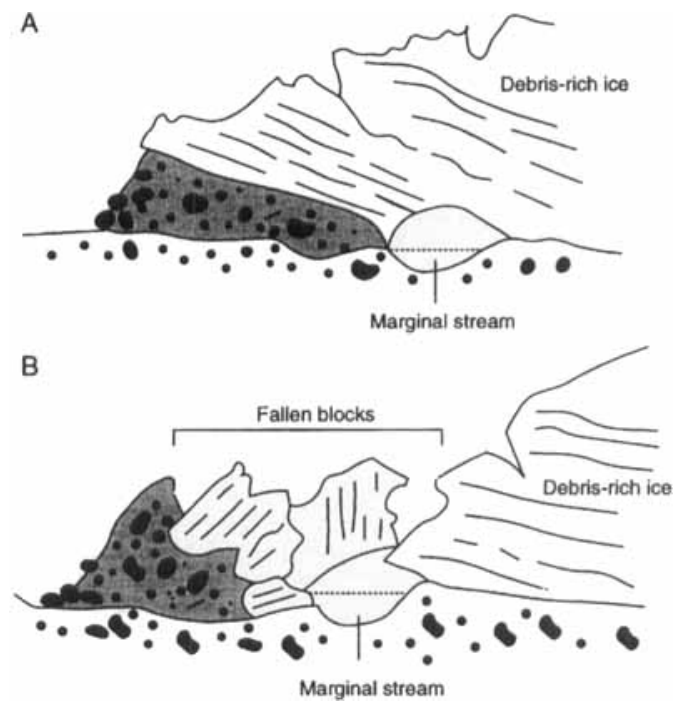

Fig. 5. Model for the development of the glaciotectonic structures observed in the ice cliff at Fridtjovbreen in July 1997.

folded and gently buckled, although the detailed geometry of these folds is difficult to follow due to the presence of displaced blocks and the broken nature of the ice surface. Secondly, there are small scale folds within debris-rich stratification. The amplitude of these folds is of the order of a few centimetres while the wavelength may vary from as little as $10 \mathrm{~mm}$ to over 1 metre. The source of this stratification is unclear; in some cases the debris contains striated and edge rounded clasts which are consistent with a basal origin, while elsewhere very angular clasts occur suggesting a supraglacial origin. The folded stratification is cross-cut by the thrusts and therefore predates them. The net result of both these debris-rich structures is the formation of an ice-cliff surface which is very debris-rich and melts out to form a distinct talus or apron beneath the ice-cliff.

Although qualitative, the observations made here suggest that polyphase deformation has taken place and is continuing to do so. A general model that explains some of the observations is outlined in Fig. 5. When the ice margin advances against the earlier lateral moraines, flow compression initiates thrusting. This entrains sediment into the body of the glacier in a similar fashion to that described from Bakaninbreen by Hambrey et al. (1996). This tectonic wedge of ice and debris appears to act as a buffer between the glacier and 


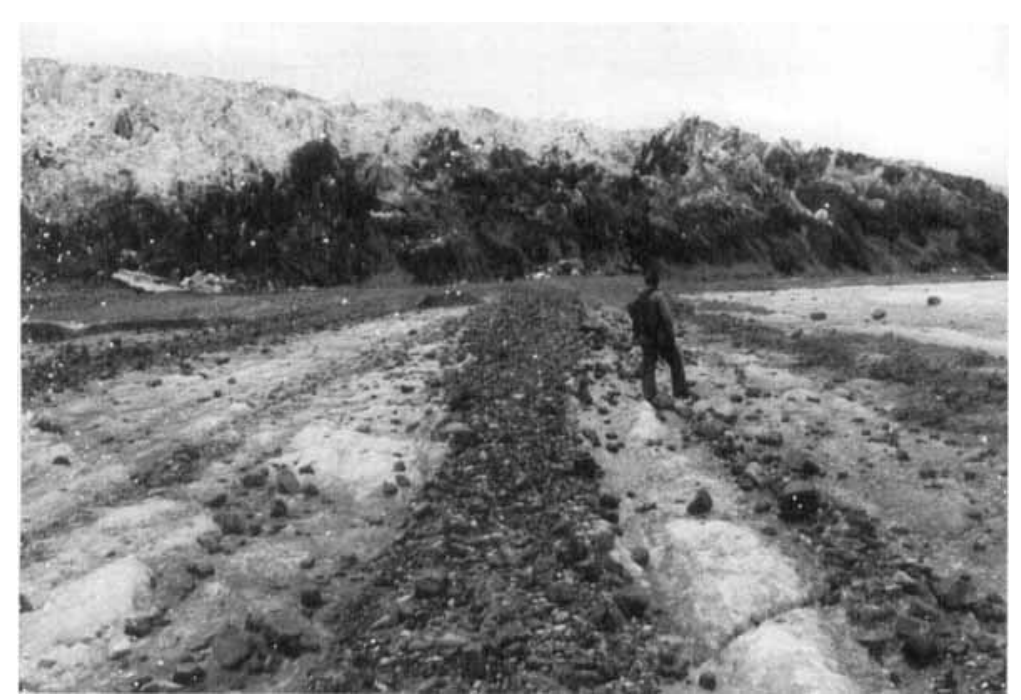

Fig. 6. Photograph of the confluence between Fridtjovbreen and Sagabreen in July 1997. Note how Fridtjovbreen is overriding the smooth tributary glacier. The medial moraines on the surface of Sagabreen can be traced under the Fridtjovbreen icecliff. the lateral moraine. Ice displacement occurs along the décollement or thrust surface upglacier of the debris-rich ice wedge. This displacement may be facilitated by a contrast in rheology between the debris-rich ice and the cleaner ice within the main body of the glacier. Deformation continues within the debris-rich wedge, but in a different tectonicstyle. This is perhaps due to a reduction in the level of compression, caused by the accommodation of shortening via the upglacier décollement surface or thrust. The thrusts within the debrisrich wedge are gently folded and a complex mélange of ice blocks and folded debris rafts is produced. Given that thrusting may be important to the landform sediment assemblage produced by a surge (Bennett et al. 1996a, 1996b; Hambrey et al. 1996; Bennett et al. in press), these observations may be of importance to understanding the landforms and sediments revealed on deglaciation. They also illustrate how the rheological properties of the ice may change during a surge due to the entrainment of debris, and thereby change the deformation regime and perhaps the landforms ultimately produced.

Significantly, debris-rich thrusts appear to be restricted to the lateral margins of Fridtjovbreen. No debris-rich thrusts were observed outcropping in the calving ice front in July 1997. This does not, however, preclude the presence of blind debris-rich thrusts that do not break the ice surface (Hambrey et al. 1996; Murray et al. 1997). These observations are consistent with the work of Hamilton \& Dowdeswell (1996) who argue that thrusts are not normally a feature of tidewater surges due to ice-marginal buoyancy.

\section{Interaction with Sagabreen}

The 1990 aerial photographs (Norsk Polarinstitutt) show Fridtjovbreen to be confluent with Grånutbreen and joined to Sagabreen by a complex of ice-cored medial moraines (Fig. 2). All three glaciers have a similar surface elevation, are relatively crevasse free, and joined to form a single flow unit prior to 1990 . The situation in 1997 is radically different, with Fridtjovbreen sitting directly on the surface of Sagabreen and Grånutbreen (Figs. 2 and 6), and with no evidence of confluent flow between the three glaciers. The situation is illustrated by the schematic profile in Fig. 7 across the Sagabreen-Fridtjovbreen confluence. The highly crevassed surface of Fridtjovbreen sits on top of Sagabreen; the contact between the two glaciers appears to be planar. A lateral meltstream runs along the junction between the two glaciers and drains the ice-dammed lakes to the north of Sagabreen (Fig. 2). Medial moraines on the surface of Sagabreen show little or no lateral or vertical displacement and can be traced directly to the marginal cliff of Fridtjovbreen where they disappear under the advancing glacier (Fig. 6). From these observations, it appears that the surfaces of Sagabreen and Grånutbreen are acting as décollement surfaces 


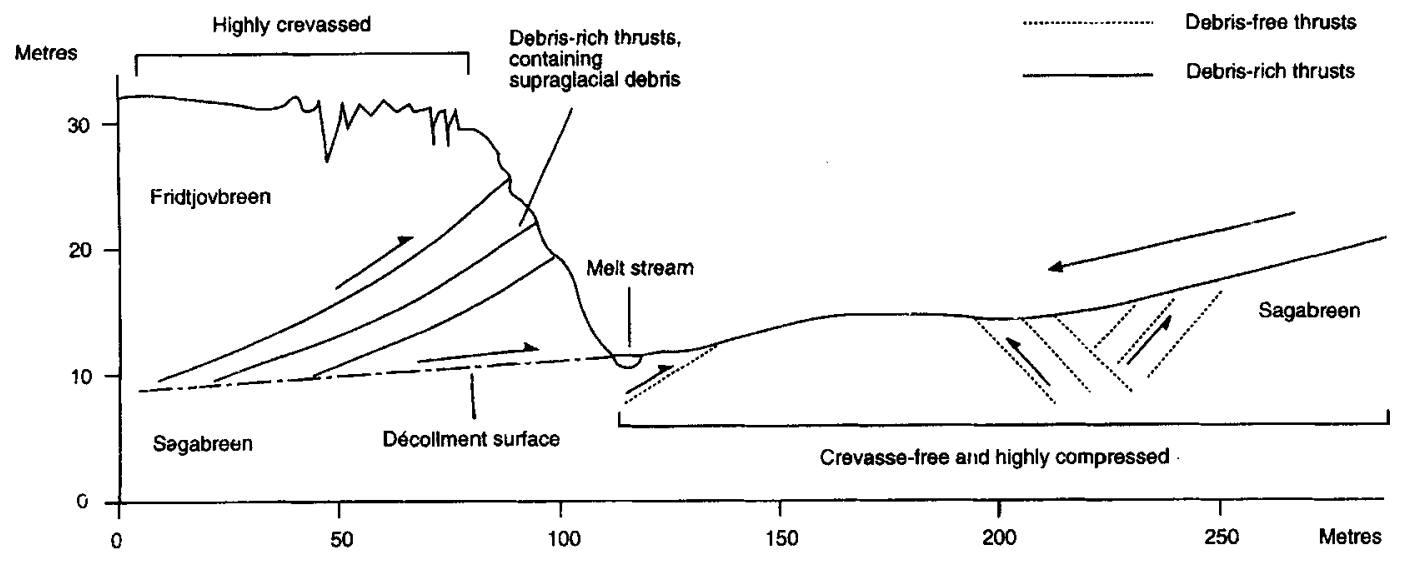

Fig. 7. Schematic longitudinal section through the confluence between Sagabreen and Fridtjovbreen parallel to ice flow on Sagabreen. The principal structures observed are shown.

for the advancing Fridtjovbreen which has ridden and continues to ride up and over the surface of the two confluent glaciers. Sagabreen appears to be unaffected by this phenomena. Few structures are present on the surface and crevasses are absent. There are, however, a few small thrust-like fractures (Lawson et al. 1994; Hambrey et al. 1996; Glasser et al. in press) which dip in opposing direction both up- and down-glacier. There is also a fracture interpreted as a thrust, dipping down-glacier, near the junction between the two glaciers. The lack of disruption to the flow characteristics of Sagabreen can be attributed to the rapidity of the advance of Fridtjovbreen and to the relatively slow response time of Sagabreen. Average Svalbard valley glacier velocities are c. 4-8 $\mathrm{ma}^{-1}$ (Hagen et al. 1993), so it is unlikely that Sagabreen has yet had time to respond to the compressional flow regime created by the rapid advance of Fridtjovbreen.

Another significant aspect of the interaction between Fridtjovbreen and Sagabreen is the recycling of material from the over-ridden medial moraines. The medial moraines on Sagabreen pass undisturbed beneath Fridtjovbreen and are composed of angular debris with a distinct suite of lithologies (micritic limestone, fine-grained conglomerate and dolerite). The debris reappears, however, englacially within Fridtjovbreen; the same suite of lithologies, unique to Sagabreen, outcrop as debris bands along thrusts within Fridtjovbreen (Fig. 7). This suggests that the décollement surface between the two glaciers acts as a sole thrust from which debris is entrained and incorporated into the thrusts within Fridtjovbreen, thereby recycling the debris.

\section{Conclusions}

In July 1997, there was no evidence that the surge of Fridtjovbreen was producing large-scale proglacial deformation of its older lateral moraines. Instead, small push moraines formed by the movement of the ice-cliff and fallen ice blocks were observed along the margin. Evidence of deformation is restricted to the lateral ice-cliff. Here, wedge-shaped units of debris-rich ice consist of an upper thrust surface separating debris-rich ice from clean ice. The debris-rich ice consists of sediment rafts incorporated along thrusts, which have subsequently been folded. This suggests polyphase deformation involving first thrusting within the ice entraining debris, followed by folding of these thrusts. This change in deformation style may reflect a change in the rheology of the ice and a change in the compressive regime. No evidence of thrusting was seen in the calving ice cliff within Fridtjovhamna, supporting the conclusions of Hamilton \& Dowdeswell (1996) that thrusts are normally absent within tidewater margins.

The confluence of Sagabreen, Grånutbreen and Fridtjovbreen shows evidence for superimposed flow units, with Fridtjovbreen overriding the surface of Sagabreen and Grånutbreen which act as décollement surfaces. This observation has 
implications for understanding the interaction of fast flowing ice streams and competing ice lobes. Initially, the idea of superimposed ice lobes was put forward by Carruthers (1953), but dismissed by the scientific community as impractical (Bennett \& Doyle 1994). Evidence from Fridtjovbreen suggests that superimposed ice lobes are possible, and that this type of interaction may affect the landform and sediment record. Future monitoring of this confluence will increase our understanding of the interaction between fast flowing and slow flowing ice masses.

Acknowledgements. - We thank Norsk Polarinstitutt and Airlift in Svalbard for logistical support during fieldwork at Fridtjovbreen in July 1997. Liverpool John Moores University and the University of Greenwich provided financial support for this project.

\section{References}

Bennett, M. R. \& Doyle, P. 1994: Carruthers and the theory of glacial undermelt: lessons from a pamphleteer? Geol. Today 10, 191-193.

Bennett. M. R., Hambrey, M. J., Huddart, D. \& Ghienne, J. F. 1996a: The formation of a geometrical ridge network by the surge-type glacier Kongsvegen, Svalbard. J. Quat. Sci. 11(6), $437-449$.

Bennett, M. R., Huddart, D., Hambrey, M. J. \& Ghienne, J. F. 1996b: Moraine development at the high-arctic valley glacier Pedersenbreen, Svalbard. Geogr. Ann. 78A(4), 209-222.

Bennett, M. R., Hambrey, M. J., Huddart, D., Glasser, N. F. \& Crawford, K. R. in press: Morphological and tectonic structure of a thrust moraine complex formed by a fast flowing or surge-type tidewater glacier, Kongsfjorden, Svalbard. Quat. Sci. Rev.

Bjömsson, H., Gjessing, Y., Hamran, S.-E., Hagen, J. O., Liestø1, O., Pálsson. F. \& Erlingsson, B. 1996: The thermal regime of sub-polar glaciers mapped by multi-frequency radio-echo sounding. J. Glaciol. 42(140), 23-32.

Boulton, G. S., Van der Meer, J. J. M., Hart, J., Beets. D.. Ruegg, G. H. J., Van der Wateren, F. M. \& Jarvis, J. 1996: Till and moraine emplacement in a deforming bed surge - an example from a marine environment. Quat. Sci. Rev. 15, 961-987.

Carruthers, R. G. 1953: Glacial drifts and the undermelt theory. Harold Hill \& Sons Ltd, Newcastle upon Tyne. 38 pp.

Clarke. G. K. C., Collins, S. G. \& Thompson, D. E. 1984: Flow, thermal structure, and subglacial conditions of a surge-type glacier. Can. J. Earth. Sci. 21(2), 232-240.

Dolgushin, L. D. \& Osipava, G. B. 1973: The regime of a surging glacier. IAHS I07, 1150-1159.

Dowdeswell, J. A., Hamilton, G. S. \& Hagen, J. O. 1991: The duration of the active phase of surge-type glaciers: contrasts between Svalbard and other regions. J. Glaciol. 37, 388-400.

Etzelmüller, B. \& Sollid, J. L. 1996: Long-term mass balance of selected polythermal glaciers on Spitsbergen, Svalbard. Norsk Geogr. Tidsskr. 50, 55-66.
Glasser, N. F., Hambrey, M. J., Crawford, K. R., Bennett, M. R. \& Huddart, D. In press: Structural glaciology of Kongsvegen, Svalbard and its role in landform genesis. J. Glaciol.

Glazovsky, A. \& Moskalevsky, M. 1989: Investigations on Fridtjovbreen in 1989. Mater. Glyatsiol. Issled 65, 148-252.

Hagen, J. O. 1987: Glacier surge at Usherbreen, Svalbard. Polar Res. 5(2), 239-252.

Hagen, J. O. \& Saetrang, A. 1991: Radio-echo soundings of sub-polar glaciers with low-frequency radar. Polar Res. $9(1)$, 99-107.

Hagen, J. O., Korsen, O. M. \& Vatne, G. 1991: Drainage pattern in a subpolar glacier: Brøggerbreen. Svalbard. In Gjessing, Y., Hagen, J. O., Hassel, K. A., Sand, K. \& Wold, B. (eds.) Arctic Hydrology. Present and Future Tasks. Oslo, Norwegian National Committee for Hydrology Report No. 23.

Hagen, J. O., Liestøl, O., Roland. E. \& Jørgensen. T. 1993: Glacier Atlas of Svalbard and Jan Mayen. Norsk Polarinst. Medd. 129.

Hambrey, M. J. \& Huddart, D. 1995: Englacial and proglacial glaciotectonic processes at the snout of a thermally complex glacier in Svalbard. J. Quat. Sci. 10, 313-326.

Hambrey, M. J., Dowdeswell, J. A., Murray, T. \& Porter, P. R. 1996: Thrusting and debris-entrainment in a surging glacier: Bakaninbreen, Svalbard. Ann. Glaciol. 22, 241-248.

Hamilton, G. S. \& Dowdeswell, J. A. 1996: Controls on glacier surging in Svalbard. J. Glaciol. 42(140), 157-168.

Hjelle, A., Lauritzen, Ø., Salvigsen, O. \& Winsnes, T. S. 1986: Geological Map of Svalbard 1:100,000 Sheet B10G Van Mijenfjorden. Norsk Polarinstitutt Temakart Nr. 2. Norsk Polarinstitutt, Oslo.

Isachsen, G. 1915: Green Harbour, Spitsbergen. Scot. Geogr. Mag, 31, 1-22.

Kamb, B. 1987: Glacier surge mechanism based on linked cavity configuration of the basal water conduit system. $J$. Geophys. Res. 92, 9083-9100.

Kamb, B., Raymond, C. F., Harrison, W. D., Engelhardt, H., Echelmeyer, K. A., Humphrey, N.. Brugman, M. M. \& Pfeffer, T. 1985: Glacier surge mechanism: 1982-1983 surge of Variegated Glacier, Alaska. Science 227(4686), 468-479.

Lawson, W. J., Sharp, M. J. \& Hambrey, M. J. 1994: The structural geology of a surge-type glacier. J. Struct. Geol. $16(10), 1447-1462$.

Meier, M. F. \& Post, A. 1969: What are glacier surges? Can. J. Earth Sci. 6(4), 807-817.

Murray, T., Gooch, D. L. \& Stuart, G. W. 1997: Structures within the surge front at Bakaninbreen, Svalbard, using ground-penetrating radar. Ann. Glaciol. 24, 122-129.

Nordenskiold, A. G. 1866: Utkast till Spetsbergens geologi. $K$. Svenska Vetenskapsakademiets Handlingar 6(7). 35 pp.

Ødegård, R. S., Hamran, S.-E., Bø, P. H., Etzelmüller, B., Vatne, G. \& Sollid, J. L. 1992: Thermal regime of a valley glacier, Erikbreen, northern Spitsbergen. Polar Res. 2(8), 69-79.

Raymond, C. F. 1987: How do glaciers surge? A review. $J$. Geophys. Res. 92, 9121-9134.

Sharp, M. J. 1985: "Crevasse-fill" ridges: a landform type characteristic of surging glaciers? Geogr. Ann. 69A, 213220 .

Sharp, M. J. 1988: Surging glaciers: geomorphic effects. Prog. Phys. Geog. 12, 533-559. 